\title{
Upaya Peningkatan Hasil Belajar Siswa Melalui Penerapan Strategi Inquiry Pada Pembelajaran Sosiologi Kelas XI IPS di SMAN 1 Batang Gasan
}

\author{
Rahmadani Fitri Hasibuan ${ }^{1}$, Ike Sylvia ${ }^{2}$ \\ ${ }^{1,2}$ Universitas Negeri Padang \\ Email: rahmadanihasibuan02@gmail.com, $\underline{\text { ikesylvia@fis.unp.ac.id }}$
}

\begin{abstract}
Abstrak
Penelitian ini dilatar belakangi oleh rendahnya nilai belajar siswa pada mata pelajaran sosiologi di kelas XI IPS SMA N 1 Batang Gasan, dengan rendahnya hasil belajar siswa ada beberapa dalam proses pembelajaran belum tercapai salah satunya strategi, adanya startegi dalam pembelajaran yang perlu diperbaharui oleh guru, salah satu solusinya dengan menerapkan strategi inquiry dalam proses pembelajaran siswa, penelitian ini bertujuan untuk mengetahui penerapan strategi inquiry dalam meningkatkan hasil belajar siswa kelas XI IPS SMA N 1 Batang Gasan. Jenis penelitian yang akan dilakukan adalah Penelitian Tindakan Kelas (PTK) dilakukan dengan jumlah siswa 25 orang di kelas XI IPS. hasil penelitian menunjukan terdapat peningkatkan hasil belajar siswa dengan menggunakan strategi inquiry. Hal ini menunjukkan secara keseluruhan belajar siswa rata-rata presentase siklus satu sebesar 35 $\%$, kemudian hasil siklus kedua mengalami peningkatan sehingga tercapai sebesar $70 \%$ sehingga dapat disimpulkan bahwa dengan menggunakan strategi inquiry dapat peningkatan. Hal ini kegiatan pembelajaran yang dilakukan dengan menyelesaikan masalah baik secara individu maupun kerjasama yang dapat mengembangkan disiplin intelktual siswa dan keterampilan berpikir sehingga akan membuat siswa berpikir kritis dan menjadikan siswa meningkatnya minat belajar sehingga akan terjadi peningkatan dalam hasil belajar siswa.
\end{abstract}

Kata kunci: Strategi inquiry, Hasil belajar, Siswa

Abstract

This research is motivated by the low value of student learning in sociology subjects in class XI IPS SMA N 1 Batang Gasan, with low student learning outcomes there are several in the learning process that have not been achieved, one of them is a strategy, there is a strategy in learning that needs to be updated by the teacher, one One solution is to apply the inquiry strategy in the student learning process, this study aims to determine the application of the inquiry strategy in improving the learning outcomes of class XI IPS SMA N 1 Batang Gasan. The type of research to be carried out is Classroom Action Research (PTK) conducted with 25 students in class XI IPS. The results showed that there was an increase in student learning outcomes using the inquiry strategy. This shows that overall student learning percentage on the first cycle is 35\%, then the results of the second cycle have increased so that it is achieved by $70 \%$ so that it can be concluded that using the inquiry strategy can increase. This is a learning activity carried out by solving problems both individually and in collaboration which can develop students' intellectual discipline and thinking skills so that it will make students think critically and make students increase interest in learning so that there will be an increase in student learning outcomes.

Keywords : Inquiry strategy, Learning outcomes, Students

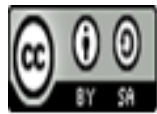

Received: July 29, $2020 \quad$ Revised: August 17, $2020 \quad$ Accepted: August 18, 2020

Jurnal Sikola: Jurnal Kajian Pendidikan dan Pembelajaran Vol. 2, No. 1, Th. 2020 


\section{Pendahuluan}

Pendidikan menurut Imam Barnadid merupakan pencangkup dari setiap perbuatan dan usaha dimana semua dari usia dini sampai dengan usia lanjut. Setiap apa yang dilakukan dan dilaksanakan tentunya penting agar dapat menambah pengetahuan, karena pengetahuan tentunya juga sangat penting. Pendidikan ialah sebuah kegiatan yang bersifat universal dimana di didalamnya terdapat kehidupan bermasyarakat juga tentunya berpengaruh pada kehidupan lingkungan bermasyarakat (Nopia, 2020) Pendidikan tidak memandang usia baik itu muda mau pun sudah tua dengan dilakukannya proses kegiatan mendapatkan ilmu maka akan membuat seseorang lebih bertambahnya pengetahuannya sehingga akan memuat seseorang perubahan dalam pemikirannya dan bertindak. Menurut (Ainissyifa, 2014) Pendidikan secara umum dengan pendidikan nasional memiliki fungsi dan tujuan yang sama dalam membentuk karakter/kepribadian yang baik terhadap peserta didik. Menurut Susanto \& B dalam konteks pembangunan manusia Indonesia seutuhnya, pengembangan pendidikan adalah alat dan alat yang penting dan menentukan untuk pengembangan sumber daya manusia. Karena itu, sektor pendidikan harus dan harus menerima perhatian, perawatan, dan prioritas dari pemerintah, masyarakat pada umunya, dan manajer pendidikan pada khususnya (Fitri \& Sylvia, 2020).

Menurut Undang-Undang Republik Indonesia Nomor 20 Tahun 2003 Tentang Sistem Pendidikan Nasional bahwa pembelajaran adalah proses interaksi peserta didik dengan pendidik dan sumber belajar yang berlangsung dalam suatu lingkungan belajar (Sanjaya, 2008). Pembelajaran dipandang secara nasional sebagai suatu proses interaksi yang melibatkan komponen-komponen utama, yaitu peserta didik, pendidik, dan sumber belajar yang berlangsung dalam suatu lingkungan belajar. Dengan demikian, proses pembelajaran merupakan suatu sistem, yaitu satu kesatuan komponen yang satu sama lain saling berkaitan dan saling berinteraksi untuk mencapai suatu hasil yang diharapkan secara optimal sesuai dengan tujuan yang telah ditetapkan. Pembelajaran merupakan usaha pendidik untuk mewujudkan terjadinya proses pemerolehan pengetahuan, penguasaan kemahiran, dan pembentukan sikap dan kepercayaan pada peserta didik agar dapat belajar dengan baik. Sehingga dengan demikian untuk dapat menghasilkan proses pembelajaran yang efektif sebagaimana yang diharapkan (Hanafy, 2014). Penilaian pengetahuan digunakan untuk mengetahui berapa dalam pengetahuan yang bisa diserap peserta didik melalaui pembelajaran berbasis authentic inquiry learning. Penilaian pengetahuan dimaksudkan untuk melihat kemampuan peserta didik menampilkan kemampuan dalam menulis, mengorganisasikan, mengekspresikan dan menjelaskan hubungan anta ride sehingga mampu menilai kemampuan berpikir tingkat tinggi peserta didik (Sylvia et al., 2019). Menurut Corey Pembelajaran adalah suatu proses dimana lingkungan seseorang secara disengaja dikelola untuk memungkinkan ia turut serta dalam tingkah laku tertentu. Dapat disimpulkan bahwa kegiatan pembelajaran yang di lakukan oleh guru dan siswa di dalam ruangan yang secara sadar membuat dan merencanakan rangkaian kegiatan yang akan di lakukan yang menghasilkan perubahan tingkah laku dan mengembangkan pengetahuan yang telah didapatkan oleh siswa (Majid, 2013). Siswa dituntut saling kerjasama dan aktif dalam memahami konsep dan menemukan fakta (Mardian \& Sylvia, 2020).

Menurut Amir B. Marvasti Sosiologi adalah ilmu sosial yang bertujuan secara empiris untuk menggali kompleksitas kehidupan manusia, disiplin ilmu artinya dia harus mengikuti prosedur yang ketat dalam prasyarat ilmiah, yaitu adanya observasi sistematik dan penejalasan yang logis. Menurut Ali Nurdin cakupan kajian sosiologi sangatlah luas mulai dari interaksi hubungan antar individu dan jalanan sampai kajian tentang proses-proses sosial yang ada diseluruh dunia (Nurdin, 1999). Menurut Aguste Comte sosiolosi merupakan ilmu pengetahuan kemasyarakatan umum yang merupakan hasil terakhir pada perkembangan ilmu pengetahuan (Marincegant, 2011). 
Menurut (Hamalik, 2000) hasil belajar adalah bila seseorang telah belajar akan terjadi perubahan tingkah laku pada orang tersebut, misalnya dari tidak tahu menjadi tahu, dan dari tidak mengerti menjadi mengerti. Menurut (Mudjiono, 2006) hasil belajar adalah tes yang diberikan pada setiap akhir pelajaran hasil yang dicapai berupa bentuk angka-angka atau skor. Menurut (Sjukur, 2012) hasil belajar adalah suatu penilaian akhir dari proses dan pengenalan yang telah dilakukan berulang-ulang serta akan tersimpan dalam rangka waktu lama atau bahkan tidak akan hilang selama-lamanya karena hasil belajar turut serta dalam membentuk pribadi individu yang selalu ingin mencapai lebih baik lagi sehingga akan merubah cara berpikir serta menghilangkan perilaku kerja yang lebih baik. Hasil bealajar adalah hasil penilaian terhadap kemampuan yang dimiliki siswa yang dinyatakan dalam bentuk angka yang diperoleh siswa dari serangkaian tes atau ujian yang diberikan guru setelah siswa mengikuti proses pembelajaran (Wasti, 2013). Pada observasi awal ini peneliti melihat bahwa minat belajar siswa masih rendah dan tergolong belum baik, dengan begitu akan berpengaruh terhadap hasil belajar siswa. Siswa yang tuntas Rata-rata persentase siswa kelas XI IPS SMA N 1 Batang Gasan $16 \%$ jumlah siswa 4 orang, data ini memperlihatkan bahwa perlunya ada pembaharuan dalam proses pembelajaran, dengan begitu peneliti menerapkan strategi inquiry dalam proses pembelajaran kelas XI IPS SMA N 1 Batang Gasan.

Strategi pembelajaran juga dapat diartikan sebagai pola kegiatan pembelajaran yang dipilih dan digunakan guru secara konstekstual, sesuai dengan karakteristik siswa, kondisi sekolah, lingkungan sekitar serta tujuan khusus pembelajaran yang dirumuskan (Anita, 2010). Strategi inquiry yang dikembangkan oleh seorang tokoh yang bernama Schuman, Schuman meyakini bahwa anak-anak merupakan individu yang penuh dengan rasa ingin tahu akan segala sesuatu. model ini bertjuan untuk melatih kemampuan peserta didik dan meneliti, menjelaskan fenomena, dan memecahkan masalah secara ilmiah. Strategi pembelajaran inkuiri adalah suatu strategi pembelajaran menekankan pada proses mencari dan menemukan. Materi pelajaran tidak diberikan secara langsung.Peran peserta didik adalah mencari dan menemukan sendiri materi pelajaran, sedangkan pedidik hanya berperan sebagai fasilitator dan pembimbing peserta didik untuk belajar (Darmansyah \& Darman, 2017). Strategi pembelajaran inquiry merupakan bentuk dari pendekatan pembelajaran yang berorientasi kepada peserta didik (student centered approach). Dikatakan demikian karena dalam strategi ini peserta didik memegang peran yang sangat dominan dalam proses pembelasjaran (Putra, 2015). Menurut Sinta strategi inquiry merupakan suatu rangkaian kegiatan belajar yang melibatkan secara maksimal seluruh kemampuan siswa untuk mencari dan menyelidik secara sistematis, kritis, logis, analisis, sehingga siswa dapat merumuskan sendiri penemuannya dengan penuh percaya diri. Siswa menyelidiki dengan mencarai informasi dan melakukan pernyataan-peryataan dan pembelajaran tugas sendiri (Lesmarani, 2017). Kurikum nasional yang digunakan dalam pembelajaran saat ini dikenal dengan nama kurikum 2013, telah memberikan arahan jelas bahwa peserta didik wajib memiliki pengalaman belajar dengan memberikan penekanan perlunya ilmiah (inquiry) agar peserta didk mampua melakukan sinkronisasi antara materi yang dipelajari dan realita yang ada disekitarnya (authentic), dengan harapan peserta didik mampu mengkonstruksi konsep serta melatih kemampuan metakognitifnya (Sylvia et al., 2019).

\section{Metode Penelitian}

Menurut (Syahdum, 2015) Penelitian Tindakan Kelas banyak dilakukan tenaga pengajar sebagai upaya pemecahan masalah dan peningkatan dan pembelajaran, jenis penelitian ini bermanfaat bagi tenaga pengajar dalam rangka meningkatkan mutu proses dan hasil pembelajaran. Penelitian Tindakan Kelas adalah suatu kegiatan penelitian dengan mencermati sebuah kegiatan belajar yang diberikan tindakan, yang secara sengaja dimunculkan dalam sebuah kelas, yang berjutuan memecahkan masalah atau meningkatkan mutu pembelajaran 
dikelas tersebut. tindakan yang secara sengaja dimunculkan tersebut diberikan guru atau berdasarkan arahan guru yang kemudian dilakukan oleh siswa (Sumardi, 2011). PTK merupakan kegiatan penelitian yang dapat dilakukan secara individu maupun kolaboratif. Penelitian Tindakan Kelas individual merupakan penelitian dimana beberapa guru melakukan penelitian secara sinergis dikelasnya dan anggota yang lain berkunjung ke kelas untuk mengamati kegiatan (Widayati, 2015). menurut Madya Penelitian Tindakan Kelas merupakan penelitian tindakan berurusan langsung dengan praktik dalam situasi alami, penelitiannya adalah pelaku praktik itu sendiri dan pengguna langsung hasil penelitiannya. lingkup ajangnya terbatas, yang paling menonjol adalah bahwa penelitian tindakan ditunjukan untuk melakukan perubahan situasi tempat penelitian dilakukan mencapai perbaikan praktik secara instrumental dan berkelanjutan (Afandi, 2014).

Penelitian dilakukan pada kelas XI IPS SMA N 1 Batang Gasan, melakukan pembelajaran dengan menggunakan strategi inquiry, dilakukan dengan dua siklus tiap satu siklus dua pertemuan pada ajaran tahun Juli-Desember 2020. Dengan memberikan soal pilihan ganda melalui google form, pengolahan data Penelitian Tindakan Kelas dilakukan dengan rumus, yaitu $: \mathrm{P}=(\mathrm{F} / \mathrm{N}) \mathrm{X} 100$ (Arikunto, 2008).

\section{Hasil dan Pembahasan}

Dilakukannya penelitian dikelas XI IPS SMA N 1 Batang Gasan dengan kegiatan dengan siklus I dan siklus II, setiap siklus terdiri dua pertemuan. Setiap pembelajaran menggunakan strategi inquiry. Berikut gambaran dari hasil pelaksanaan penelitian yang telah di lakukan. Kegiatan pembelajaran yang dilakukan mendapatkan hasil penelitian yaitu, sebagai berikut :

\section{Siklus Pertama pertemuan pertama}

Siklus pertama pada pertemuan pertama diberikan materi mengenai pengertian integrasi sosial hasil yang di dapatkan sebagai berikut :

\section{Tabel 1. Hasil belajar siswa kelas XI IPS SMA N 1 Batang Gasan Siklus 1 Pertemuan 1}

\begin{tabular}{ccccc} 
No & $\begin{array}{c}\text { Rentang } \\
\text { Nilai }\end{array}$ & $\begin{array}{c}\text { Klasifikasi } \\
\text { Nilai }\end{array}$ & $\begin{array}{c}\text { Jumlah } \\
\text { Siswa }\end{array}$ & $\begin{array}{c}\text { Persentase } \\
\text { Siklus I }\end{array}$ \\
\hline 1 & $86-100$ & A & 2 & \\
\hline 2 & $81-85$ & B & 0 & \multirow{2}{*}{$30 \%$} \\
\cline { 1 - 3 } 3 & $75-80$ & $\mathrm{C}$ & 4 & \\
\hline & $>74$ & $\mathrm{D}$ & 14 & \\
\hline
\end{tabular}

Sumber: Hasil tugas individu melalui google forms

Hasil belajar yang siklus pertama pertemuan pertama dilakukan tugas individu melalui google forms dengan materi pengertian integrasi sosial menggunakan startegi inquiry, siswa yang mendapatkan rentang nilai tertinggi ada 2 orang, yang mendapatkan klasifikasi nilai B tidak ada dan klasifikasi nilai $\mathrm{C}$ ada 4 orang dan yang tidak tuntas berjumlah 14 , orang dari persentase yang didapatkan sebesar $30 \%$.

\section{Siklus Pertama pertemuan dua}

Pada siklus pertama pertemuan kedua menggunakan materi faktor-faktor penghambat dan faktor-faktor pendorong integrasi sosial yang di dapatkan hasil belajar sebagai berikut : 
Rahmadani Fitri Hasibuan, Ike Sylvia Upaya Peningkatan Hasil Belajar Siswa Melalui Penerapan Strategi Inquiry pada Pembelajaran Sosiologi Kelas XI IPS di SMA N 1 Batang Gasan

Tabel 2. Hasil belajar siswa kelas XI IPS SMA N 1 Batang Gasan Siklus Pertama Pertemuan kedua

\begin{tabular}{ccccc} 
No & $\begin{array}{c}\text { Rentang } \\
\text { Nilai }\end{array}$ & $\begin{array}{c}\text { Klasifikasi } \\
\text { Nilai }\end{array}$ & $\begin{array}{c}\text { Jumlah } \\
\text { Siswa }\end{array}$ & $\begin{array}{c}\text { Persentase } \\
\text { Siklus I }\end{array}$ \\
\cline { 1 - 4 } 1 & $86-100$ & $\mathrm{~A}$ & 3 & \\
\cline { 1 - 4 } 2 & $81-85$ & $\mathrm{~B}$ & 0 & \multirow{2}{*}{$40 \%$} \\
\cline { 1 - 3 } 3 & $75-80$ & $\mathrm{C}$ & 5 & \\
\hline
\end{tabular}

Sumber: Hasil tugas individu melalui google form

Pada siklus pertama pertemuan kedua dengan materi faktor-faktor penghambat dan faktorfaktor pendorong integrasi sosial menggunakan strategi inquiry diperoleh hasil belajar yang dilakukan tugas individu melalui google form hasil nilai tertinggi dicapai 3 siswa dan yang menengah klasifikasi nilai $\mathrm{B}$ tidak ada dan klasifikasi nilai $\mathrm{C}$ sebanyak 5 orang dan yang tidak tuntas sebanyak 12 siswa rata-rata presentase nilai siswa pada pertemuan kedua ini sebesar $40 \%$. Berdasarkan hasil belajar siswa yang dilakukan peneliti pertemuan satu dan pertemuan kedua pada siklus pertama, hasil perbandinagn anatara ke dua pertetemuan tersebut mengalami peningkatan dilihat melalui tabel sebagai berikut:

Tabel 3. Hasil konversi hasil belajar siswa belajar sosiologi siswa kelas XI IPS 1 Siklus Pertama

\begin{tabular}{ccccc} 
No & $\begin{array}{c}\text { Rentang } \\
\text { Nilai }\end{array}$ & $\begin{array}{c}\text { Klasifikasi } \\
\text { Nilai }\end{array}$ & $\begin{array}{c}\text { Jumlah } \\
\text { Siswa }\end{array}$ & $\begin{array}{c}\text { Persentase } \\
\text { Siklus I }\end{array}$ \\
\hline 1 & $86-100$ & A & 5 & \\
\cline { 1 - 3 } 2 & $81-85$ & B & 0 & \multirow{2}{*}{$35 \%$} \\
\cline { 1 - 3 } 3 & $75-80$ & C & 9 & \\
\hline 4 & $>74$ & D & 26 & \\
\cline { 1 - 2 } & & &
\end{tabular}

Sumber: Hasil belajar siswa pertemuan satu dam pertemuan kedua

Berdasarkan tebel diatas, maka dapat kita lihat bahwa terdapat peningkatan dari pertemuan pertama dengan pertemuan kedua dilakukan pada siklus pertama. Pertemuan pertama siklus pertama rata-rata presentase sebesar 30\% dan pertemuan ke dua siklus pertama sebesar $40 \%$ terdapat peningkatan $10 \%$, antara pertemuan pertema dan pertemuan kedua persentasi siklus pertama sebesar $35 \%$.

\section{Siklus Kedua Pertemuan Pertama}

Pada siklus kedua pertemuan pertama materi proses terbentuknya integrasi sosial dan bentuk-bentuk integrasi sosial hasil yang diperoleh sebagai berikut:

Tabel 4. Hasil belajar siswa kelas XI IPS SMA N 1 Batang Gasan Siklus Kedua Pertemuan Pertama

\begin{tabular}{ccccc} 
No & $\begin{array}{c}\text { Rentang } \\
\text { Nilai }\end{array}$ & $\begin{array}{c}\text { Klasifikasi } \\
\text { Nilai }\end{array}$ & $\begin{array}{c}\text { Jumlah } \\
\text { Siswa }\end{array}$ & $\begin{array}{c}\text { Persentase } \\
\text { Siklus II }\end{array}$ \\
\hline 1 & $86-100$ & A & 4 & \\
\cline { 1 - 3 } 2 & $81-85$ & B & 0 & \multirow{2}{*}{$60 \%$} \\
\cline { 1 - 3 } 3 & $75-80$ & C & 8 & \\
\hline 4 & $>74$ & D & 8 & \\
\hline
\end{tabular}

Sumber: Hasil tugas individu melalui google forms 
Berdasarkan hasil belajar yang diperoleh siswa melalui tugas individu dibuat di google forms materi proses pembentukan integrasi sosial dan bentuk-bentuk integrasi sosial pada siklus kedua pertemuan pertama, nilai siswa yang paling tinggi atau klasifikasi nilai A sebanyak 4 orang sedangkan klasifikasi nilai B tidak ada dan yang nilai klasifikasi nilai $\mathrm{C}$ sebanyak 8 dan tidak tuntas sebanyak 8 orang hasil nilai rata-rata presentase siswa pada pertemuan ini sebanyak $60 \%$.

\section{Siklus Kedua Pertemua Kedua}

Siklus kedua pada pertemuan kedua menggunakan materi reintegrasi dan proses reintegrasi hasil yang diperoleh sebagai berikut

Tabel 5. Hasil belajar siswa kelas XI IPS SMA N 1 Batang Gasan Siklus Kedua Pertemuan Kedua

\begin{tabular}{ccccc} 
No & Rentang Nilai & $\begin{array}{c}\text { Klasifikasi } \\
\text { Nilai }\end{array}$ & $\begin{array}{c}\text { Jumlah } \\
\text { Siswa }\end{array}$ & $\begin{array}{c}\text { Persentase Siklus } \\
\text { II }\end{array}$ \\
\cline { 1 - 3 } 1 & $86-100$ & A & 2 & \\
\cline { 1 - 3 } 2 & $81-85$ & B & 0 & \multirow{2}{*}{$80 \%$} \\
\cline { 1 - 3 } 3 & $75-80$ & C & 14 & \\
\hline
\end{tabular}

Sumber: hasil tugas individu melalui google forms

Pertemuan kedua disiklus dua menggunakan materi reintegrasi sosial dan proses reintegrasi sosial yang dibantu oleh strategi inquiry perolehan hasil tugas individu yang dilalkukan siswa melalui google forms siswa yang memperoleh nilai paling tinggi sebanyak 3 orang dan yang mendapat klasifikasi B tidak dan klasifikasi C sebanyak 14 orang dan siswa yang tidak tuntas ada 4 orang rata-rata presentase siswa pada pertemuan ini sebanyak $70 \%$.

Berdasarkan hasil yang diperoleh pertemuan pertama dan pertemuan kedua di siklus dua ini hasil perbandingan dapat di lihat pada tabel dibawah ini:

Tabel 6. Hasil konversi hasil belajar siswa belajar sosiologi siswa kelas XI IPS 1 Siklus 1

\begin{tabular}{ccccc} 
No & Rentang Nilai & $\begin{array}{c}\text { Klasifikasi } \\
\text { Nilai }\end{array}$ & $\begin{array}{c}\text { Jumlah } \\
\text { Siswa }\end{array}$ & $\begin{array}{c}\text { Persentase Siklus } \\
\text { II }\end{array}$ \\
\hline 1 & $86-100$ & $\mathrm{~A}$ & 6 & \\
\cline { 1 - 3 } 2 & $81-85$ & $\mathrm{~B}$ & 0 & \multirow{2}{*}{$70 \%$} \\
\hline 3 & $75-80$ & $\mathrm{C}$ & 22 & \\
\hline 4 & $>74$ & $\mathrm{D}$ & 12 & \\
\hline
\end{tabular}

Sumber: Hasil belajar siswa pertemuan satu dam pertemuan kedua

Dapat kita lihat tabel diatas, bahwa terjadi peningkatan hasil belajar siswa dari pertemuan pertama dengan perteman kedua pada siklus dua Berdasarkan tebel diatas, maka dapat kita lihat bahwa terdapat peningkatan dari pertemuan pertama dengan pertemuan kedua dilakukan pada siklus dua. Pertemuan pertama siklus dua rata-rata presentase sebesar $60 \%$ dan pertemuan ke dua siklus dua sebesar $80 \%$ terdapat peningkatan $10 \%$, antara pertemuan pertema dan pertemuan kedua persentasi siklus 1 sebesar $70 \%$. 
Rahmadani Fitri Hasibuan, Ike Sylvia Upaya Peningkatan Hasil Belajar Siswa Melalui Penerapan Strategi Inquiry pada Pembelajaran Sosiologi Kelas XI IPS di SMA N 1 Batang Gasan

\section{Pembahasan}

Tiap pertemuan pembelajaran yang diberikan tugas individu mengalami peningkatan hasil belajar dengan dibantu menggunakan startegi inquiry, rata-rata presentase siklus pertama dan siklus kedua sebagai berikut:

Tabel 7. Hasil konversi hasil belajar siswa belajar sosiologi siswa kelas XI IPS 1 Siklus Pertama dan Siklus Kedua

\begin{tabular}{|c|c|c|c|c|c|c|}
\hline No & $\begin{array}{c}\text { Rentang } \\
\text { Nilai }\end{array}$ & $\begin{array}{l}\text { Klasifikasi } \\
\text { Nilai }\end{array}$ & $\begin{array}{c}\text { Jumlah } \\
\text { Siswa }\end{array}$ & $\begin{array}{l}\text { Persentase } \\
\text { Siklus I }\end{array}$ & $\begin{array}{c}\text { Jumlah } \\
\text { Siswa }\end{array}$ & $\begin{array}{l}\text { Persentase } \\
\text { Siklus II }\end{array}$ \\
\hline 1 & $86-100$ & A & 5 & \multirow{4}{*}{$35 \%$} & 6 & \multirow{4}{*}{$70 \%$} \\
\hline 2 & $81-85$ & B & 0 & & 0 & \\
\hline 3 & $75-80$ & $\mathrm{C}$ & 9 & & 22 & \\
\hline 4 & $>74$ & $\mathrm{D}$ & 26 & & 12 & \\
\hline
\end{tabular}

Sumber: Hasil belajar siswa pertemuan satu dam pertemuan kedua

Terlihat jelas tabel diatas dari siklus pertama menuju siklus kedua adanya peningkatan yang signifikan. Dari proses pembelajaran yang telah dilalui siswa melalui daring (online) terdapat beberapa kendala salah satu siswa yang tidak mempunya HP (handpone) bebrapa harus pergi meminjam ke tetangga untuk belajar ada juga sama sekali tidak ikut dalam proses pembelajaran sebanyak 5 orang terkendala alat komunikasi yang digunakan pada pembelajaran, kendala selanjutnya kurangnya minat belajar siswa dan rasa tanggung jawab siswa terhadap tugas yang diberikan oleh guru, dengan diterapkannya siklus kedua siswa semakin ingin tahu karena siklus pertam guru memberikan masalah dan diminta siswa yang menyelesaikannya, namun siklus kedua guru mengirim video ke group whatsApp siswa kelas XI IPS dalam video di buat semenarik mungkin agar siswa lebih penasaran dan setelah siswa mengamati video guru meminta siswa untuk menyimpulkannya dan harus ada pertanyaan yang akan di ajukan ke kelompok yang sedang presentasi, dengan begitu terdapat peningkatan hasil belajar siswa kelas XI IPS SMA N 1 Batang Gasan.

Penelitian ini dilakukan untuk melihat peningkatan hasil belajar tidak di lakukan secara tatap muka atau pembelajaran di dalam kelas, namun pembelajaran dilakukan dengan secara daring (online) pembelajaran yang dibantu oleh aplikasi WhatsApp salah satunya group yang dibuat untuk berkomunkasi dalam kegiatan proses pembelajaran, berhubung adanya virus corona tidak bisa pembelajaran di lakukan seperti biasanya. Peningkatan tiap siklus cukup baik terlihat adanya perubahan- minat belajar siswa mulai dilihat dari siklus pertema awalnya siswa masih ada sebagian yang rasa malas yang dituri dan tidak mau tau, ketika siklus kedua berlangsung dengan menggunakan startegi inquiry rasa penasaran lebih tinggi dan dalam menyelesaikan masalah pun lebih berpikir kritis menjawab permasalahn yang diberikan oleh guru.

Pada siklus kedua rasa ingin tahu siswa pun menigkat dan guru memberikan tugasnya yanga ada disekeliling masyarakat agar siswa lebih mudah mengamati permasalahan yang ada, setelah siswa paham dengan materi yang dibawakan maka guru memberikan tugas individu agara nantinya guru bisa melihat seberapa paham dalam mengikuti proses belajar. Sehingga dapat kita lihat perbandingan antara pratinadakan,siklus pertama dan siklus kedua sebagai berikut: 
Rahmadani Fitri Hasibuan, Ike Sylvia Upaya Peningkatan Hasil Belajar Siswa Melalui Penerapan Strategi Inquiry pada Pembelajaran Sosiologi Kelas XI IPS di SMA N 1 Batang Gasan

Tabel 8. Perbandingan Pratindakan,Siklus Pertama dan Siklus Kedua

\begin{tabular}{|c|c|c|c|c|c|c|c|c|}
\hline No & $\begin{array}{c}\text { Rentang } \\
\text { Nilai }\end{array}$ & $\begin{array}{l}\text { Klasifikasi } \\
\text { Nilai }\end{array}$ & $\begin{array}{c}\text { Jumlah } \\
\text { Siswa }\end{array}$ & $\begin{array}{l}\text { Persentase } \\
\text { Pratindakan }\end{array}$ & $\begin{array}{c}\text { Jumlah } \\
\text { Siswa }\end{array}$ & $\begin{array}{c}\text { P. } \\
\text { Siklus I }\end{array}$ & $\begin{array}{c}\text { Jumlah } \\
\text { Siswa }\end{array}$ & $\begin{array}{c}\text { P. } \\
\text { Siklus II }\end{array}$ \\
\hline 1 & $86-100$ & A & 0 & \multirow{4}{*}{$16 \%$} & 5 & \multirow{4}{*}{$35 \%$} & 6 & \multirow{4}{*}{$70 \%$} \\
\hline 2 & $81-85$ & B & 0 & & 0 & & 0 & \\
\hline 3 & $75-80$ & C & 4 & & 9 & & 22 & \\
\hline 4 & $>74$ & $\mathrm{D}$ & 22 & & 26 & & 12 & \\
\hline
\end{tabular}

Dapat kita lihat berdasarkan data observasi yang dilakukan oleh peneliti pada kelas XI IPS SMAN 1 Batang Gasan. Pada setiap siklus terdapat peningkatan terhadap hasil belajar dari pra tindakan sebesar $16 \%$, siklus I terdapat peningkatan yang dilakukan dengan strategi inquiry sebesar $35 \%$, peningkatan yang dilihat pada siklus I berlanjut dengan siklus II untuk menghasilkan proses pembelajaran yang baik dilakukannya siklus II dengan strategi inquiry sebesar $70 \%$, dari kegiatan pembelajaran tersebut terlihat peningkatan setiap siklus.

Hal ini pada pra tindakan belum adanya penerapan startegi inquiry setalah masuk ke siklus pertama mulai penerapan startegoi inquiry langsung ada peningkatan, dari hasil siklus pertama belum maksimal maka dilakukan siklus kedua dengan digantinya dalam kegiatan pembelajaran dengan adanya video yang dibuat oleh peneliti maka rasa ingin tahu siswa semakin meningkat dan tugas yang diberikan kepada siswa ditanggung jawabi oleh siswa karena sudah meningkatnya minat belajar siswa.

\section{Kesimpulan}

Berdasar hasil belajar yang dilakukan dengan dua siklus empat pertemuan proses pembelajaran di lakukan dengan berdiskusi, di terapkannya strategi inquiry dapat dilihat hasil rata-rata persentase siswa kelas XI IPS Batang Gasan yang tuntas siklus I yaitu 35\% dan rata-rata persentase siswa kelas XI IPS Batang Gasan yang tuntas siklus II yaitu 70\% dengan begitu terlihat bahwa dengan strategi inquiry dapat meningkatkan hasil belajar siswa kelas XI IPS Batang Gasan.

\section{Daftar Pustaka}

Afandi, M. (2014). Pentingnya Penelitian Tindakan Kelas Bagi Guru Dalam Pembelajaran di Sekolah Dasar. http://lppm-unissula.com/Jurnal.Unissula.Aid/Index.Php/Pendas/Artic 1e/ ViewFile/639/563.

Ainissyifa, H. (2014). Pendidikan Karakterdalam Perspektif Pendidikan Islam. https://journal.uniga.ac.dd/Index.Php/JP/Article/ViewFile/68/69.

Anita, S. (2010). Strategi Pembelajaran. http://Respository.ut.ac.id/40331/PKOP/4301-M1.Pdf.

Arikunto, S. (2008). Penelitian Tindakan Kelas. Jakarta: Bumi Aksara.

Darmansyah, D \& Darman, R. A. (2017). Strategi Pembelajaran. Bandung: Erka CV Rumahkayu Pustaka Utama.

Fitri, R., \& Sylvia, I. (2020). Pengaruh Model pembelajaran Kooperatif Tipe Snowball Throwing Terhadap Hasil Belajar Sosiologi Siswa Kelas XI IIS di SMAN 1 Batu Sangkar. Jurnal Sikola, 1(3), 239-245. https://doi.org/https://doi.org/10.24036/sikola.vli3.34

Hamalik. (2000). Proses Belajar Mengajar. Jakarta: Bumi Aksara.

Hanafy, M. S. (2014). Konsep Belajar dan Pembelajaran. http://journal.uinalauddin.ac.id/ Index.Php/Lentera_pendidikan/Article/ViewFile/516/491.

Undang-Undang Republik Indonesia Nomor 20 Tahun 2003 tentang Sistem Pendidikan Nasional. 
Lesmarani, S. (2017). Upaya Meningkatkan Hasil Belajar Siswa Pada Pembelajaran IPA Materi Perubahan Lingkungan Menggunakan Strategi Inquiry Di Kelas IV MIS Mutiara Sei Mencirim Kecamatan Sunggal Tahun Ajaran 2016-2017. http://prepository.uinsu.ac.id/ 68851/Skripsi/20Sinta/20Lesmarani.Pdf.

Majid, A. (2013). Strategi Pembelajaran. Jakarta: PT Remaja Rosdakarya.

Mardian, W., \& Sylvia, I. (2020). Upaya Meningkatkan Keaktifan Belajar Melalui Penerapan Model Student Division Achievement Divisions di XI IPS 1 SMAN 1 Bukittinggi. Jurnal Sikola, 1(3), 208-215. https://doi.org/10.1007/s11139-020-00300-y

Marincegant, Y. (2011). Pengantar Sosiologi. https://repository.unikom.ac.id/38729/1/ Pengantar/20Sosiologi/231.Pdf.

Mudjiono, D. dan. (2006). Belajar dan Pembelajaran. Jakarta: Rineka Cipta.

Nopia, E. (2020). Pendidikan Anak Menurut Prof.Dr. Qurais Shihab MA Dalam Persfektif Tafsir Al-Misbah Surat Luqman Ayat 13-19. Skripsi. Universitas Islam Negeri Raden Intan Lampung.

Nurdin, A. (1999). Sosiologi Organisasi: Pengertian, Sejarah Lahirnya, Ruang Lingkup, Manfaat dan Metode Penelitian. http://www.pustaka.ut.ac.id/Lib/Wp-Content/Uploads/Pdfmk/ SOSI431003-M1.Pdf.

Putra, C. (2015). Upaya Meningkatkan Hasil Belajar IPS Dengan Menggunakan Strategi Pembelajaran Inkuiri (SPI). http://umpalangkarya.ac.id./Index.Php/Bitnet/Article/ Download/753/702

Sanjaya, W. (2008). Kurikulum dan Pembelajaran: Teori dan Praktik Pengembangan Kurikulum Tingkat Satuan Pendidikan (KTSP). Jakarta: Kencana.

Sjukur, S. B. (2012). Pengaruh Blended Learning Terhadap Motivasi Belajar dan Hasil Belajar Siswa Tingkat SMK. https://journal.uny.ac.id/Index.Php/Jpv/Article/ViewFile/ $1043 / 844$.

Sumardi, K. (2011). Penelitian tindakan kelas. http://kaminsumardi.staf.upi.edu/Files/2011/ 10/Penelitian-Tindakan-Kelas.Pdf.

Syahdum, R. A. T. R. (2015). Penelitian Tindakan Kelas. http://repository.uinsu.ac.id/2464/ 1/ISI/20Penelitian/20Tindakan/20Kelas.Pdf.

Sylvia, I., Anwar, S., \& Khairani, K. (2019). Pengembangan Instrumen Penilaian Autentik Berbasis Pendekatan Authentic Inquiry Learning Pada Mata Pelajaran Sosiologi di Sekolah Menengah Atas. Socius, 6(2), 103-115. https://doi.org/10.24036/scs.v6i2.162

Wasti, S. (2013). Hubungan Minat Belajar Dengan Hasil Belajar Mata Pelajaran Tata Busana Di Madrasah Alyah Negeri 2 Padang. http://ejournal.unp.ac.id/Index.Php/Jhet/ Article/View/File/1032/869.

Widayati, A. (2015). Penelitian Tindakan Kelas. https://journal.uny.ac.id/Index.Php/Jpakun/ Article/ViewFile/1793/1487. 